\title{
Evaluating the Influence of Succession Planning on the Growth of Small and Medium Enterprises (SMEs) in Ahafo, Bono and Bono East Regions of Ghana
}

\author{
Vida Korang1* ${ }^{*}$ Moses Kwaku Golly², Opoku Mustapha Osman ${ }^{1}$ \\ ${ }^{1}$ Catholic University College of Ghana, Fiapre, Sunyani, Ghana \\ ${ }^{2}$ Faculty of Applied Sciences \& Technology, Sunyani Technical University, Sunyani, Ghana \\ Email: *vdkorang@gmail.com, moseskwakugolly@gmail.com
}

How to cite this paper: Korang, V., Golly, M. K., \& Osman, O. M. (2021). Evaluating the Influence of Succession Planning on the Growth of Small and Medium Enterprises (SMEs) in Ahafo, Bono and Bono East Regions of Ghana. Open Journal of Business and Management, 9, 3076-3091. https://doi.org/10.4236/ojbm.2021.96172

Received: October 8, 2021

Accepted: November 27, 2021

Published: November 30, 2021

Copyright $\odot 2021$ by author(s) and Scientific Research Publishing Inc. This work is licensed under the Creative Commons Attribution International License (CC BY 4.0).

http://creativecommons.org/licenses/by/4.0/ (c) (i) Open Access

\begin{abstract}
Small and medium businesses (SMEs) are critical to any country's national economic development. On the other hand, SMEs confront a considerable difficulty in succession planning: the lack of or inefficiency/ineffectiveness of succession planning. As a result, this quantitative correlational study aimed to evaluate the influence of succession planning on the growth of Small and Medium Enterprises (SMEs) in the Brong Ahafo region of Ghana. To reach the research goal, the study used a quantitative correlational research design. Data were collected from 140 respondents involved in SMEs from nine districts and municipal assemblies from the Bono, Ahafo and Bono East Regions of Ghana. The results revealed that most of the respondents, 113 (80.64\%), agreed that employees or possible successors might leave the organisation for a better offer and $106(75.71 \%)$ respondents indicated that owners of SMEs do not think about succession plan until there is a crisis. The results also showed that succession plan explains nearly (50\%); thus, half the chances of survival of an SME in the Bono, Ahafo and Bono East regions are dependent on succession planning. There was a significant difference in succession plan practices among the different year groups of SMEs. The result also demonstrated no statistically significant difference in the service and manufacturing industries' succession planning practices among the SMEs surveyed. It is recommended that business owners, policymakers and the state should support SMEs in succession planning development. If possible, succession planning should be part of the school curriculum and entrepreneurship training programmes in schools and business institutes. This will build the capacity of prospective business owners and create awareness about the effects of succession planning on the growth of organisations.
\end{abstract}




\section{Keywords}

Succession Planning, SMEs, Organizational Growth

\section{Introduction}

Small and medium-sized enterprises (SMEs) are critical to every country's development. Ghana has around a hundred and fifteen thousand small and medium businesses (General, 2015). There is mounting evidence that SMEs play a critical role in any country's national economic development (Pisani \& Yoskowitz, 2004). They provide a significant contribution to a country's Gross Domestic Product (GDP); they provide substantial employment opportunities for many people and easily adjust to changes in the business environment (Nicolau, 2015). Small and medium-sized businesses (SMEs) create most new jobs and generate much of the creativity and innovation that drives economic growth (Akpan \& Ukpai, 2017; Pisani, 2015). SMEs address issues such as unemployment, poverty, and regional disparities (Dasanayaka, 2011). There is evidence that countries like China have been able to achieve economic transformation through supporting and boosting entrepreneurship among their SMEs. As of 2017, China had 40 million small and medium-sized enterprises (SMEs), according to Wang and Kondoh (2018). They pointed out that this accounted for 99 percent of all businesses, 60 percent of Chinese GDP, 50 percent of tax income, and 80 percent of urban employment. Due to their enormous numbers and geographical distribution, Indian Micro Small Medium Size Enterprises (MSMEs) continue to contribute to the country's economic growth and employment generation, according to Jain and Jain (2014). In 2011-2012, the total estimated income of registered MSMEs in India was 31 million (Jain \& Jain, 2014). According to a report on China's Enterprise Management Project Industry, there were 40 million small and medium-sized enterprises (SMEs) in China in 2017.

However, these SMEs encounter various obstacles that limit their ability to contribute effectively to the country's economic progress. One of these difficulties is a lack of succession planning. The importance of succession planning in safeguarding the business's well-being and continuity cannot be overstated (Akpan \& Ukpai, 2017). According to Bogdany et al. (2014), having a sound succession plan is one thing that small business owners can provide to society. However, succession planning in SMEs is frequently overlooked, and it is left to nature to run its course. According to Saan et al. (2018), the European Commission estimates that around 1.5 million small enterprises in Europe are in danger of failing due to succession issues. As a result, the importance of SMEs in contributing to the nation's development after the original owner retires or is incapacitated due to ill-health or dies cannot be overlooked. Again, there is a significant distinction between large business succession planning and small business succession planning (Kim, 2017). While large firms have a well-regulated and well-es- 
tablished framework, SMEs' succession planning is frequently unregulated and left to chance (Bogdany et al., 2013). According to popular belief, SMEs in Ghana pay little or no attention to this area of their operations.

According to Minichilli et al. (2014) and Bogdany et al. (1994), success without succession will inevitably lead to collapse. This indicates that having a profitable firm without succession is pointless. Many firms (over 70\% in Ghana) fail because critical players quit the company when they retire or die due to poor succession planning (Domfeh, 2011; Saan et al., 2018). Most SMEs are similarly reliant on their owners as managers for day-to-day operations. They may not function even for a few days if the owner is absent or unavailable (Jain \& Jain, 2014). They emphasised that this dependence has a significant impact on the business's survival after the owner is permanently unavailable due to retirement or death, as there may not be a successor to properly take over the management of the business, rendering the original owner's efforts meaningless (Jain \& Jain, 2014). As a result of inadequate company succession, only $30 \%$ of SMEs survive to the second generation. Less than $17 \%$ survive to the third generation of the original owners, according to Jain and Jain (2014).

In the United Kingdom, the Small Business Service Department estimated in 2005 that enterprises without strategies for the generational shift would lose 400,000 staff (Scholes et al., 2008). According to Hayes et al. (2015), two out of every three small businesses in America willfully ignore succession planning, and just $35 \%$ of small enterprises have a succession plan. This information is not even available in a developing country like Ghana. According to Ogundele et al. (2012), as referenced by Ifekwem (2018), a business owner's death, retirement, or incapacity poses a substantial difficulty for the business if there is no business succession plan in place. They gave examples of successful firms in Nigeria such as Ojukwu Transport, Ugo Foam, Sanusi Brothers, Osondu Transports, Henri Fajemirokun, Ekene Dili Chukwu Motors Bashorun M.K.O Abiola in the 1950s, 1960s, and 1970s that are no longer in operation due to a lack of succession planning. Ifekwem (2018) stated again that the long-term viability of successful enterprises such as the Dangote Group, Ibeto Group, Innoson Motors, Chisco Transport, and Cutix Industries, among others, will be determined by the extent to which successors are prepared. For a country like Ghana, especially in the Ahafo, Bono, and Bono East Regions, it was clear that the majority of enterprises found were new. For example, a conversation with Kyeremeh, a famous businessman who owned over 7 SMEs and was named "Business Personality of the Year" for the former Brong Ahafo Region in 2014, revealed that most of the firms that existed in the 1960s in the then Brong Ahafo Region are no longer in operation. Mr. Kyeremeh mentions Nyame Tease Construction Limited, S. Y. Barnie Company Limited, and E. T. Nkrumah Company Limited, among others.

The non-perpetual existence of these businesses could be as a result of a lack of succession planning. Akpan and Ukpai (2017) stated that most small busi- 
nesses lack succession planning, a significant cause of their high mortality. From our literature search, little information exists on SMEs' succession planning in Ghana (Eyiah et al., 2018; Mensah \& Nyadu-Addo, 2012), which forms the basis for this study. The study, therefore, set out to examine the influence of succession planning on the growth of Small and Medium Enterprises (SMEs) in Ghana. The researchers proposed the following research questions: what challenges confront succession planning in SMEs? What is the relationship between succession planning and the growth of SMEs? What are the differences between succession planning and the age, size and type of SMEs? This research impacts critical stakeholders or policymakers, existing and new businesses. The study's outcome would also help companies formulate suitable programs, improve organisational performance through succession planning, and serve as a reference for future knowledge generation. Besides, some limitations of the study included: only small-medium businesses with less than 100 employees located in and operating from the Bono and Ahafo Regions were considered. The study was influenced by the researchers' biases, having been born and raised in the study area and witnessing the extinction of most businesses. This study should have ideally been conducted throughout Ghana. However, due to time and financial constraints, the study only focused on a sample population of businesses in Ghana's Bono and Ahafo Regions. The interpretation of words like "strongly agree" and "agree" in the Likert-type scale may change from one participant to the next, leading to imprecise responses. However, the validation and reliability tests guarded against this potential delimitation.

\section{Materials and Methods}

\subsection{Research Design}

This study used descriptive and quantitative research designs to achieve the research objectives. The philosophical perspective of this study is in line with the empiricist position. This study, therefore, formulated a hypothesis, made observations, reviewed documents, collected data, analysed the data, tested it, and made conclusions. Knowledge gained from this research is based on observation and pursuing scientific methods. Our position as researchers is therefore in line with that of the empiricist.

\subsection{Population and Sampling Strategy}

Data for the study were drawn from SMEs within the Bono, Ahafo and Bono East Regions of Ghana. Business owners, relatives of the business owners, and employees were considered for this study. The sectors of the businesses were in the field of commerce, Agriculture, manufacturing, construction and media. These businesses were selected from the database of the Ghana Revenue Authority (GRA). These were made up of 2000 active taxpayers as of 2015 at the GRA (GRA-STO, 2015). The sample frame was the SMEs in Bono Ahafo and Bono 
East Regions. First, the 2000 SMEs who were active taxpayers in the Ghana Revenue Authority (GRA) database as per 2015 data were targeted. A first purposive selection resulted in 200 SMEs. The purposive sampling method was used because the selection was based on SMEs that have seen transition or gone through a change of leadership, have long-serving employees, or employees that have worked for the previous administration for institutional memory purposes. To attain a representative sample size, the researcher chose a sample size of $140 \mathrm{cal}-$ culated using the formula of Adam (2020), yielding a sample size of 134, which was approximated to 140 distributed as in Table 1 below.

\subsection{Research Instrument}

The study employed a questionnaire as the main instrument for data collection. The use of questionnaires gave a lot of advantages to the researcher. The questionnaires were completed anonymously and also inexpensive to administer. Again, it was distributed to many people in a short period; hence, a great deal of data was gathered in a short time (McCusker \& Gunaydin, 2015). The instrument for the study went through the processes of both face and content validity. Pilot-test was done with ten (10) SMEs to subject the research instrument to field testing with a population similar to that of the sample for the study in the Sunyani West Assembly using a purposive sampling technique. The piloted data was analysed using SPSS obtaining a Cronbach alpha of 0.87 . The rule of thumb states that Cronbach Alpha of 0.6 or more indicates the instrument's internal consistency (Pallant, 2013). The Cronbach Alpha of 0.87 obtained is far above the required minimum threshold of 0.6.

Table 1. Sampled municipalities and district assemblies for the study.

\begin{tabular}{ccc}
\hline Municipality/District Assembly & Frequency & Percentage \\
\hline Asutifi South & 3 & 2.14 \\
Tano North District Assembly & 3 & 2.14 \\
Berekum Municipality & 21 & 15.00 \\
Dormaa Ahenkro Municipality & 21 & 15.00 \\
Tano South Assembly & 7 & 5.00 \\
Tain District Assembly & 6 & 4.29 \\
Kintampo Municipality & 11 & 7.86 \\
Asutifi North District Assembly & 11 & 7.86 \\
Sunyani Municipality & 23 & 16.43 \\
Techiman Municipality & 19 & 13.57 \\
Wenchi District Assembly & 15 & 10.71 \\
Total & $\mathbf{1 4 0}$ & 100.00 \\
\hline
\end{tabular}

Source: Field data, 2017. 


\subsection{Data Collection Method}

A survey was conducted using self-administered questionnaires for business owners and entrepreneurs purposely selected from SMEs in Ahafo, Bono and Bono East Regions. Five (5) field enumerators were recruited and trained to assist in administering the questionnaire. The field enumerators availed themselves to the respondents at their places of business to answer questions that bordered respondents. The questionnaires were delivered, answered, and collected on the same day. This resulted in a $100 \%$ response rate.

\subsection{Ethical Consideration}

The participants were told that their responses would be kept private and that their identities would never be revealed. Participants received a letter informing them of the research's fundamental details, such as the study's goal. They were given a consent form to sign stating they either accept or reject participation in the study. Thus, participants were not to participate in this research under duress.

\subsection{Data Analysis}

The responses to the questionnaire items were analysed using Statistical Package for Social Science (SPSS) Version 20. The responses in the questionnaires were edited and coded to ensure consistency. The responses for the open-ended questions were grouped based on common ideas that the respondents expressed. The results were analysed using descriptive and inferential statistics (Table 2).

The following hypotheses were propounded to address the research questions two (RQ2) and three (RQ3);

RQ2; Relationship between succession planning and growth of SMEs

$\mathrm{H}_{0}$ : There is no significant relationship between succession planning and the development of SMEs.

$\mathrm{H}_{1}$ : There is a significant relationship between succession planning and the growth of SMEs

Table 2. Statistical techniques for the study.

\begin{tabular}{lcc}
\hline Research Questions & Statistical Techniques & Reasons for the Technique Used \\
\hline $\begin{array}{l}\text { Research Question One (RQ1) } \\
\text { What challenges confronting succession planning } \\
\text { in SMEs }\end{array}$ & $\begin{array}{c}\text { Proportions, averages and } \\
\text { Standard Deviations } \\
\text { Correlation Analysis }\end{array}$ & $\begin{array}{c}\text { Descriptive tool to identify the challenges } \\
\text { confronting succession planning in SMEs }\end{array}$ \\
\hline
\end{tabular}

\section{Research Question Two (RQ2)}

What is the relationship between succession planning and the growth of SMEs?

\section{Research Question Three (RQ3)}

What are the differences between succession planning and the age, size and type of SMEs?
Independent Samples t-test

To establish the relationship between succession planning and the growth of SMEs

To determine whether there is a significant difference between succession plan and the types of SMEs, the sizes of SMEs and the age of SMEs 
RQ3; Differences that exist between succession planning and the age, size and the type of SMEs

1) $H_{0}$ : There is no significant difference between succession planning practices and the age of SMEs.

$\mathrm{H}_{1}$ : There is a significant difference between succession planning practices and the age of SMEs.

2) $\mathrm{H}_{0}$ : There is no significant difference between succession planning practices in manufacturing and service enterprises.

$\mathrm{H}_{1}$ : There is a significant difference between succession plan practices in manufacturing and service enterprises.

3) $\mathrm{H}_{0}$ : There is no significant difference between succession planning practices in small and medium enterprises.

$\mathrm{H}_{1}$ : There is a significant difference between succession plan practices in small and medium enterprises.

\section{Results and Discussion}

\subsection{Demographic Statistics}

The regional breakdown of the registered SMEs selected from 9 Municipal and District Assemblies of the then Bono Ahafo and Bono East Regions are displaced in Table 3 below. The highest respondents (26) came from the Sunyani Municipality, with the least respondents (7) from Tano North District. Sunyani Municipality recorded the highest number of respondents as Sunyani is the oldest capital town among the three regional capitals, allowing it to host most of the SMEs. Tano North district is a newly created district in the Ahafo Region with limited facilities and business opportunities.

Table 3 shows detailed information on the respondents based on variables such as age, sex, level of education, the position of the respondents in the SMEs, the number of years of operation, the type of industry, and the size of the enterprise. Concerning the age of respondents, it was identified that $87 \%$ of the respondents forming the majority were within the age range of 20 to 49 years (Table 3). This reflects the active working population of most countries, of which Ghana is no exception. The Ghana Statistical Service gave the working population of the country to be from 18 to 60 years. A majority of the respondents (66\%) were married, 37\% were never married, and the rest were divorced, widowed, in informal/consensual union, or separated. Again, a marginal majority of the respondents (37.14\%) had attained tertiary education, followed by secondary education (30\%), whereas middle/junior high school leavers were $19.29 \%$. The rest of the respondents were either vocational education $(1.71 \%)$ or postsecondary $(2.8 \%)$ leavers (Table 3 ). Furthermore, a majority of the respondents (66\%) had been in service for up to 9 years, with $37 \%$ from 10 to over 20 years (Table 3). Concerning employment status, a majority of the respondents representing $79 \%$, were permanently engaged in their organisations, while the others were either on a contract or casual engagement. Regarding the age of the orga- 
nisations, $33.09 \%$ of respondents said their organisations had been in existence for between 5 and 9 years, forming the majority. Another 17.9\% of the respondents said their organisations were 20 years and over, with $17.27 \%, 16.55 \%$, and $11.51 \%$ operating for 0 to 4 years, 10 to 14 years and 15 to 19 years respectively.

Table 3. Regional breakdown of registered SMEs and profile of respondents.

\begin{tabular}{|c|c|c|c|}
\hline Region & Municipality/District & Frequency & Percent (\%) \\
\hline \multirow{2}{*}{ Ahafo } & Tano South District & 7 & 5.00 \\
\hline & Tano North District & 3 & 2.14 \\
\hline \multirow{4}{*}{ Bono } & Sunyani Municipality & 26 & 18.57 \\
\hline & Sunyani West District & 17 & 12.15 \\
\hline & Berekum Central Municipal & 21 & 15.00 \\
\hline & Dormaa District & 21 & 15.00 \\
\hline \multirow{4}{*}{ Bono East } & Kintampo Municipal & 11 & 7.86 \\
\hline & Techiman Municipal & 19 & 13.57 \\
\hline & Wenchi Municipal & 15 & 10.71 \\
\hline & Total & 140 & 100.00 \\
\hline \multirow[t]{5}{*}{ Variable, $N(140)$} & Category & Frequency & Percent (\%) \\
\hline & 20 to 29 years & 42 & 30.00 \\
\hline & 30 to 39 years & 42 & 30.00 \\
\hline & 40 to 49 years & 41 & 29.29 \\
\hline & 50 and over & 15 & 10.71 \\
\hline \multirow{2}{*}{ Sex } & Male & 90 & 64.29 \\
\hline & Female & 50 & 35.71 \\
\hline \multirow{5}{*}{ Level of Educational } & Basic Education & 27 & 19.29 \\
\hline & Secondary Education & 42 & 30.00 \\
\hline & Vocational/Technical & 15 & 10.71 \\
\hline & Post-Secondary & 4 & 2.86 \\
\hline & Tertiary & 52 & 37.14 \\
\hline \multirow{2}{*}{ Type of industry } & Service & 112 & 80.00 \\
\hline & Manufacturing & 28 & 20.00 \\
\hline \multirow{2}{*}{ Age of Organization } & Less than 10 years & 76 & 54.30 \\
\hline & Between $10 \& 20$ years and over & 64 & 45.70 \\
\hline
\end{tabular}

Source: Field data, 2017. 


\subsection{Challenges Attributable to Succession Plan}

RQ1 (Table 2) focused on determining the challenges that SMEs face in their succession plan decisions. Two descriptive statistics were employed in fulfilling this objective. Firstly, an attempt was made to examine respondents' level of agreement to the variables posing the challenges. Secondly, the summaries of responses were provided using the mean and the standard deviations. The results are shown in Table 4 and Table 5, respectively. With respect to the level of agreement, Table 4 presents the responses to the variables outlined as challenges attributable to succession plans among SMEs in the Ahafo, Bono, and Bono East Regions of Ghana. Five (5) points Likert scale ( $1=$ strongly disagree, $2=$ disagree, $3=$ neutral, $4=$ agree, and $5=$ strongly agree) was employed.

Table 4. Challenges attributable to succession plan.

\begin{tabular}{|c|c|c|c|c|c|}
\hline Variable & 1 & 2 & 3 & 4 & 5 \\
\hline & $\mathrm{F}(\%)$ & $\mathrm{F}(\%)$ & F (\%) & F (\%) & $\mathrm{F}(\%)$ \\
\hline $\begin{array}{l}\text { SMEs do not think about succession planning until } \\
\text { there is a crisis. }\end{array}$ & $\begin{array}{l}10 \\
(7.14)\end{array}$ & $\begin{array}{l}16 \\
(11.41)\end{array}$ & $\begin{array}{l}8 \\
(5.72)\end{array}$ & $\begin{array}{l}40 \\
(28.57)\end{array}$ & $\begin{array}{l}66 \\
(47.14)\end{array}$ \\
\hline Founders fear of losing their organization & $\begin{array}{l}9 \\
(6.43)\end{array}$ & $\begin{array}{l}7 \\
(5.0)\end{array}$ & $\begin{array}{l}19 \\
(13.57)\end{array}$ & $\begin{array}{l}35 \\
(50.0)\end{array}$ & $\begin{array}{l}35 \\
(25.0)\end{array}$ \\
\hline $\begin{array}{l}\text { SMEs have no succession planning guidelines and } \\
\text { programmes in place }\end{array}$ & $\begin{array}{l}16 \\
(11.29)\end{array}$ & $\begin{array}{l}22 \\
(22.58)\end{array}$ & $\begin{array}{l}25 \\
(17.74)\end{array}$ & $\begin{array}{l}45 \\
(32.26)\end{array}$ & $\begin{array}{l}23 \\
(16.13)\end{array}$ \\
\hline $\begin{array}{l}\text { SMEs owners do little in retaining, nurturing and } \\
\text { developing their employees }\end{array}$ & $\begin{array}{l}13 \\
(9.52)\end{array}$ & $\begin{array}{l}18 \\
(12.70)\end{array}$ & $\begin{array}{l}27 \\
(19.05)\end{array}$ & $\begin{array}{l}56 \\
(39.60)\end{array}$ & $\begin{array}{l}27 \\
(19.05)\end{array}$ \\
\hline $\begin{array}{l}\text { SMEs owners give little or no thought to the } \\
\text { challenges of their leadership }\end{array}$ & $\begin{array}{l}11 \\
(8.20)\end{array}$ & $\begin{array}{l}14 \\
(9.84)\end{array}$ & $\begin{array}{l}50 \\
(36.07)\end{array}$ & $\begin{array}{l}39 \\
(27.87)\end{array}$ & $\begin{array}{l}25 \\
(18.03)\end{array}$ \\
\hline $\begin{array}{l}\text { Employee or a possible successor may leave the } \\
\text { business for a better offer }\end{array}$ & $\begin{array}{l}5 \\
(3.23)\end{array}$ & $\begin{array}{l}7 \\
(4.84)\end{array}$ & $\begin{array}{l}16 \\
(11.29)\end{array}$ & $\begin{array}{l}79 \\
(56.45)\end{array}$ & $\begin{array}{l}34 \\
(24.19)\end{array}$ \\
\hline $\begin{array}{l}\text { Employee or a possible successor may not have an } \\
\text { interest in the business }\end{array}$ & $\begin{array}{l}9 \\
(6.67)\end{array}$ & $\begin{array}{l}14 \\
(10.0)\end{array}$ & $\begin{array}{l}33 \\
(23.33)\end{array}$ & $\begin{array}{l}58 \\
(41.67)\end{array}$ & $\begin{array}{l}26 \\
(18.33)\end{array}$ \\
\hline
\end{tabular}

Source: Fieldwork, 2017.

Table 5. Summary of responses on challenges facing SMEs in Bono, Ahafo Bono East Regions.

\begin{tabular}{lcccc}
\hline \multicolumn{1}{c}{ Variable } & $\mathrm{N}$ & Sum & Mean & Std. Dev. \\
\hline No managerial guidelines for a succession plan & 140 & 374.00 & 2.671 & 1.437 \\
Leaders do little in recruiting, nurturing & 140 & 422.00 & 3.014 & 1.319 \\
Owners do little in addressing the challenges of SP & 140 & 438.00 & 3.129 & 1.335 \\
Employees leave the organisation & 140 & 529.00 & 3.779 & 1.025 \\
Employees may not have an interest in the business & 140 & 463.00 & 3.307 & 1.263 \\
SMEs do not give attention to succession planning & 140 & 519.00 & 3.707 & 1.202 \\
Founders fear losing their organisations & 140 & 490.00 & 3.500 & 1.272 \\
\hline
\end{tabular}

Source: Field data 2017. 
The results in Table 4 show that the majority of the respondents, 113 representing $80.64 \%$, agreed that employees or possible successors might leave the organisation for better offers, which was closely followed by 106 (75.71\%) respondents agreeing that owners of SMEs do not think about succession plan until a crisis arose as one of the challenges facing SMEs succession planning in the then Bono, Ahafo and Bono East Regions. Other challenges postulated by respondents included lack of interest by a possible successor in the business, founder's fear of losing their organisation, SMEs owners doing little in retaining, nurturing and developing their employees or potential successors.

Additionally, sixty-eight (68), representing $48.39 \%$ of respondents, agreed to the challenge that SMEs have no succession planning guidelines and programmes in place. To further understand the challenges facing succession planning, the researchers summarised the results using the means and the standard deviations, as shown in Table 5 .

The results in Table 5 indicate that most of the respondents agree that these variables are the main challenges they are confronted with as they plan for succession. Except for the variable "no managerial guidelines for a succession plan," which had a mean of $2.671(\approx 3.0=$ neutral $)$ and standard deviation of 1.437 , all the variables had averages greater than 3.00 , with the highest being 3.779 , the measure of variation being 1.025 . These findings confirmed the results shown in Table 4 and the results of other studies as per these examples. Harter (2008) identified it as a big challenge when resources are spent developing a potential successor, only for the successor to leave for other offers, making it difficult to plan for the future. Again, Timbe and Sira (2013) recognised leadership as vital in succession planning implementation. However, they indicated that leaders in most organisations do very little in recruiting, nurturing and developing their pools of talents to ensure continuity, similar to the finding of this current research. Timbe and Sira (2013) noted that it makes it difficult for such organisations to fill key positions when it becomes vacant, making business owners not have an excellent conclusion to their leadership. The result is also in line with the challenges identified in the PwC's Annual Corporate Directors Survey (Katz \& McIntosh, 2012). Most organisations do not give full attention to succession planning until a crisis forces it onto the agenda. This knee-jerking and reactive approach to succession planning is a recipe for doom as it might be too late for the effective selection of a successor (Minichilli et al., 2014). Timbe and Sira (2013) again stated that these challenges might serve as a threat to the growth of SMEs, hence must be curbed. In line with this suggestion, an effort was made by the current study to seek proposals to address some of the challenges facing SMEs with respect to succession planning and the recommendations made by respondents are shown in Table 6 below.

The results reveal that none of the respondents disagreed with the recommendations. Expressly, 131 out of the 140 respondents, representing 93.6\%, indicated that organisations should be encouraged to practice succession planning, 
Table 6. Suggestions to improve succession planning in SMEs.

\begin{tabular}{lccccc}
\hline \multicolumn{1}{c}{ Variable } & $\mathbf{1}$ & $\mathbf{2}$ & $\mathbf{3}$ & $\mathbf{4}$ & $\mathbf{5}$ \\
\cline { 2 - 5 } & $\mathbf{F ~ ( \% )}$ & $\mathbf{F ~ ( \% )}$ & $\mathbf{F ~ ( \% ) ~}$ & $\mathbf{F ~ ( \% )}$ & $\mathbf{F ~ ( \% ) ~}$ \\
\hline Organisations should be encouraged to practice succession planning & $0(0)$ & $0(0)$ & $9(6.4)$ & $36(25.7)$ & $95(67.9)$ \\
The need for training on succession planning & $0(0)$ & $0(0)$ & $10(7.1)$ & $52(37.1)$ & $78(55.7)$ \\
The need for policy on succession planning & $0(0)$ & $2(1.4)$ & $11(7.9)$ & $47(33.6)$ & $80(57.1)$ \\
There should be efforts to retain employees & $0(0)$ & $0(0)$ & $12(8.6)$ & $56(40.0)$ & $72(51.4)$ \\
\hline
\end{tabular}

Source: Field data 2017.

92.8\% recommended the need for training of SME owners in the succession planning process. The results further indicated a need for a policy on succession planning, and those business owners should make an effort to retain employees in the organisation; these represented $90.7 \%$ and $91.4 \%$, respectively.

\subsection{The Relationship That Exists between Succession Planning and the Growth of Organisations}

The RQ3 focused on establishing the relationship between succession plans and the growth of SMEs in the Bono Ahafo and Bono East regions of Ghana. To achieve this, the researchers hypothesised that "there is no significant relationship between succession plan and the growth of SMEs", and correlation analysis was performed. Pallant (2011) indicated that correlation analysis is used to determine the relationship between two variables. For this study, the two variables are succession plan and growth of SMEs, with succession plan being the independent variable (IV) and growth of SMEs as the dependent variable (DV). In reviewing the literature on a succession plan and the growth of SMEs, it was identified that various variables come together to provide an effective succession plan and growth. These variables in the succession plan were computed into a single variable. The growth of SMEs was also done in the same manner to obtain the two variables for the correlation analysis using Statistical Package for Service Solution (SPSS) version 20.0, and Table 7 below displays the result.

The result in Table 7 indicates that the number of cases, $\mathrm{N}$ is 140 , which shows that there were no missing data. The results also reveal a positive $(r=$ 0.695) relation between succession plans and the growth of SMEs. The result further indicated a strong relationship between succession plans and the development of SMEs since $r=0.695$ is higher than 0.5 (Pallant, 2011). To provide more understanding on how much that succession plan can explain the growth of SMEs, the coefficient of determination was computed as $r^{2}=(0.695)^{2} \times 100=$ $48.30 \%$. This means that the succession plan explains $48.30 \%$ nearly $50 \%$ of the growth of SMEs in the Bono, Ahafo and Bono East regions. Consequently, half the chance of the survival of SMEs in these regions is dependent on succession planning. Lastly, the Correlation is significant at the 0.01 level (2-tailed). This indicates how much confidence one should have in the result obtained. 
Table 7. Correlations analysis between succession plan and growth of SMEs.

\begin{tabular}{cccc}
\hline \multicolumn{2}{c}{ Variables } & Success Plan & Growth of SMEs \\
\hline \multirow{3}{*}{ Success Plan } & Pearson Correlation & 1 & $0.695^{* *}$ \\
& Sig. (2-tailed) & & 0.000 \\
N & 140 & 140 \\
\hline \multirow{2}{*}{ Growth of SMEs } & Pearson Correlation & $0.695^{* *}$ & 1 \\
& Sig. (2-tailed) & 0.000 & 140 \\
\hline
\end{tabular}

Source: Field data 2017.

\subsection{The Variance between Succession Planning and the Age, Size and the SME Types}

SMEs in Ghana can be grouped in different forms. However, for this study, SMEs are categorised into new and old, manufacturing \& service and small, medium \& large enterprises. This section of the study was to determine if there was any significant difference in how these enterprises manage their succession planning. To achieve the objective; the researchers tested three hypotheses as follow:

$\mathrm{H}_{1}$ : There is no significant difference between succession planning practices in the new and the old enterprises.

$\mathrm{H}_{2}$ : There is no significant difference between succession planning practices in manufacturing and service enterprises.

$\mathrm{H}_{3}$ : There is no significant difference between succession planning practices in small, medium and large enterprises.

For $\mathrm{H}_{1}$, the study examined whether there is a significant difference between succession plans in enterprises verse duration of existence, as indicated in Table 3. In testing the hypothesis $\left(\mathrm{H}_{1}\right)$, analysis of variance (ANOVA) was performed using the SPSS to compare the variance, that is, the variability in scores, between different ages of the SMEs; Table 8 showcases the result.

The analysis results shown in Table $8\left(\mathrm{H}_{1}\right)$ indicate that statistically, there was a significant difference in the succession plan practices of SMEs in the three different age groups, with $\mathrm{F}(2,138)=5.499, p=0.020$. This implies a significant difference in succession plan practices among the various year groups of SMEs in Ghana's Bono, Ahafo and the Bono East regions. We, therefore, reject the null hypothesis $\left(\mathrm{H}_{0}\right)$ (section 2.6, RQ3).

To ascertain a possible difference in the SMEs succession planning and the types of enterprise, section 2.6, RQ3; $\mathrm{H}_{2}$ examined the differences between the manufacturing and service industries with respect to succession planning practices: Independent samples t-test was used, and the result from the analysis is shown in Table 8. The outcome of the analysis displays the means and the standard deviations for each group, service industry (73.06 \pm 9.66$)$ and manufacturing industry $(71.43 \pm 15.12)$, as well as the number of cases (responses) in 
Table 8. Variances between succession planning and the age, size and the SME types.

\begin{tabular}{cccccc}
\hline \multicolumn{5}{c}{ H1: ANOVA for Succession Plan and the Age of SMEs } \\
\hline Variables & Sum of Squares & Df & Mean Square & F & Sig. \\
\hline Between Groups & 635.416 & 2 & 635.416 & 5.499 & 0.020 \\
Within Groups & $15,945.805$ & 138 & 115.549 & & \\
Total & $16,581.221$ & 140 & & & \\
H2: Independent $t$-test Analysis & of Succession Plan and SME Industry Type \\
\hline Type of Industry & Means & Df & Standard Dev. & \multirow{2}{*}{ Sig (2-tailed) } \\
\hline Serving (112) & 73.06 & 138 & 9.66 & 0.707 & 0.481 \\
Manufacturing (28) & 71.43 & \multicolumn{5}{c}{15.12} & & \\
\hline \multicolumn{7}{c}{ H3: ANOVA for Succession Plan and the Size of SMEs } & \\
\hline Variables & Sum of Squares & Df & Mean Square & F & Sig. \\
\hline Between Groups & 1023.147 & 2 & 511.574 & 4.505 & 0.013 \\
Within Groups & $15,558.074$ & 138 & 113.563 & & \\
Total & $16,581.221$ & 140 & & & \\
\hline
\end{tabular}

*Significant at 0.05 (Source: Field data, 2017).

each category; 112 and 28 respectively. The result also demonstrates that $\mathrm{t}(2$, 138) $=0.707, p=0.481$, implies no significant difference in the succession planning practices of the service industry and manufacturing industry among the SMEs surveyed. Therefore, we reject the alternative hypothesis and uphold the null hypothesis.

Lastly, the third hypothesis $\left(\mathrm{H}_{3}\right.$, Table 8$)$ looked at the differences in succession planning practices in small, medium, and large enterprises. Analysis of variance (ANOVA) was performed since three groups are forming the independent variable, and the results from the statistical analysis are displayed in Table 8. The results indicate that $\mathrm{F}(2,138)=4.505, p=0.013$, demonstrating a statistically significant difference in SMEs' succession planning practices in the three different categories (small, medium and large enterprises) organisation. We, therefore, reject the null hypothesis and uphold that there is a significant difference among succession planning practices in the small, medium and large enterprises and concluded that differences exist in succession planning practices with respect to the size of SMEs.

\section{Conclusion}

The study set out to examine the influence of succession planning on the growth of Small and Medium Enterprises (SMEs) in Ghana. Concerning the relationship between succession planning and the growth of SMEs, the study has established a strong positive relationship between the two variables; thus, if a business owner fails to prepare and nurture a successor, the business will fail. The results on the differences in succession planning practices with respect to age, size, and 
type of SMEs have established differences among these variables except the SME type. This implies that SMEs of different ages and sizes manage their succession planning differently, indicating the nonexistence of standardised policy guidelines regarding succession planning may not ensure consistency and continuity among the SMEs, which may affect the realisation of the crucial roles played by SMEs such as employment creation, contribution to GDP and development of society at large. In the light of the positive relationship between succession planning and the growth of SMEs, business owners, policymakers and the state should support SMEs in succession planning development. If possible, succession planning should be part of the school curriculum and entrepreneurship training programmes in schools and business institutes. This will build the capacity of prospective business owners and create awareness about the effects of succession planning on the growth of organisations. Further, in building the capacity of their organisational members, business owners should provide employees with the opportunity for professional development through training and job shadowing or rotation for positions identified through needs-driven assessment.

\section{Conflicts of Interest}

The authors declare no conflicts of interest regarding the publication of this paper.

\section{References}

Adam, A. M. (2020). Sample Size Determination in Survey Research. Journal of Scientific Research and Reports, 26, 90-97. https://doi.org/10.9734/jsrr/2020/v26i530263

Akpan, P. L., \& Ukpai, K. A. (2017). Succession Planning and Survival of Small-Scale Businesses in Benue State. International Journal of Scientific and Research Publications, 7, 408-411.

Bogdany, E., Balogh, A., \& Csizmadia, T. (1994). Leadership Succession and the Origin of Successor in Hungarian SMEs. Management and Marketing (M\&M), 9, 283.

Bogdany, E., Balogh, A., \& Csizmadia, T. (2014). Leadership Succession and the Origin of Successor in Hungarian SMEs. Management \& Marketing, 9, 283.

Bogdany, E., Balogh, A., Csizmadia, T., \& Polak-Weldon, R. (2013). The Change in Size of SMEs in Light of Succession. In Active Citizenship by Knowledge Management \& Innovation: Proceeding of the Management, Knowledge and Learning International Conference (pp. 671-678).

Dasanayaka, S. (2011). Global Challenges for SMEs in Sri Lanka and Pakistan in Comparative Perspectives. Business Review, 6, 61-81.

Domfeh, J. A. (2011, May 22). The Fate of Small and Medium Enterprises in Kumasi (p. 16). Daily Graphic.

Eyiah, K. A., Kheni, N. A., \& Acquah, R. (2018). SME Financing Constraints: Evidence from the Survey of Construction Firms in Ghana. International Journal of Small and Medium Enterprises and Business Sustainability, 3, 23-47.

General, R. (2015). Registrar-General's Department-Ghana (SME Class).

Harter, L. (2008) Succession Planning Part II: Business Succession Is a Team Sport. Journal of Practical Estate Planning, 10, 23-30. 
Hayes, J. P., Chawla, S. K., \& Kathawala, Y. (2015). A Comparative Study of Problems Encountered in the Development of Small Businesses in the US and Mexico. The Journal of Developing Areas, 49, 395-406. https://doi.org/10.1353/jda.2015.0175

Ifekwem, N. E. (2018). Preparing Successor and Family Business Sustainability in SouthEast, Nigeria. Pacific Journal of Science and Technology, 19, 196-205.

Jain, S. K., \& Jain, N. (2014). Business Succession Planning in Indian MSM-FOBEs: A Study Based on Managerial-Role Employees. Global Business Review, 15, 517-530. https://doi.org/10.1177/0972150914535138

Katz, D. A., \& McIntosh, L. A. (2012). Corporate Governance Update Advice for the Board in CEO Selection and Succession Planning. New York Law Journal.

Kim, Y. (2017). Succession Planning and Management in Non-Profit Organisations. In J. K. A. Word, \& J. E. Sowa (Eds.), The Nonprofit Human Resource Management Handbook (pp. 101-121). Routledge. https://doi.org/10.4324/9781315181585-7

Mensah, M. S. B., \& Nyadu-Addo, R. (2012). Juxtaposition of the Role of Small Businesses and the State in Ghana's Economic Development. International Business \& Management, 5, 75-82.

McCusker, K., \& Gunaydin, S. (2015). Research Using Qualitative, Quantitative or Mixed Methods and Choice Based on the Research. Perfusion, 30, 537-542. https://doi.org/10.1177/0267659114559116

Minichilli, A., Nordqvist, M., Corbetta, G., \& Amore, M. D. (2014). CEO Succession Mechanisms, Organisational Context, and Performance: A Socio-Emotional Wealth Perspective on Family-Controlled Firms. Journal of Management Studies, 51, 1153-1179. https://doi.org/10.1111/joms.12095

Nicolau, C. (2015). Are SMEs Still Profitable in an Economic Crisis? Qualitative Research on Romanian Entrepreneurship and Crisis Management. Bulletin of the Transylvania University of Brasov, Series V: Economic Science, 8, 217-232.

Ogundele, O. J., Idris, A. A., \& Ogundipe, K. (2012). Entrepreneurial Succession Problems in Nigeria's Family Business: A Threat to Sustainability. European Scientific Journal, 8, 208-227.

Pallant, J. (2011). SPSS Survival Manual: A Step by Step Guide to Data Analysis Using the SPSS Program (4th ed.). Allen \& Unwin.

Pallant, J. (2013). SPSS Survival Guide: A Step by Step Guide to Data Analysis Using SPSS. Alllen \& Unwin.

Pisani, M. J. (2015). Does Informality Impact Formal Sector Firms? A Case study from Nicaragua. The Journal of Developing Areas, 49, 317-334. https://doi.org/10.1353/jda.2015.0033

Pisani, M. J., \& Yoskowitz, D. W. (2004). Microcredit and Micro and Small Enterprise Development in Belize, Central America: A Qualitative Study of the Small Farmers and Business Bank, Ltd. Latin American Business Review, 5, 45-69. https://doi.org/10.1300/J140v05n01 03

Saan, R., Boateng, J., \& Kamwine, S. (2018). Succession Planning and Family-Owned Business Continuity in the Wa Municipality. International Journal of Innovative Research and Development, 2, 304-309.

Scholes, L., Westhead, P., \& Burrows, A. (2008). Family Firm Succession: The Management Buy-Out and Buy-in Routes. Journal of Small Business and Enterprise Development, 15, 8-30. https://doi.org/10.1108/14626000810850829

Timbe, M. W., \& Sira, F. (2013). Challenges Facing Succession Management in the Ke- 
nyan Civil Service: (A Case Study of Nairobi County in the Ministry of Education). International Journal of Enhanced Research in Management Computer Applications, 2, $18-23$.

Wang, Y., \& Kondoh, T. (2018). A Study on Business Succession in Small and MediumSized Chinese Enterprises. Chinese Business Review, 17, 524-531.

https://doi.org/10.17265/1537-1506/2018.10.004 